\title{
Financial Flexibility on Required Returns: Vector Autoregression Return Decomposition Approach*
}

\author{
Sang-Giun YIM ${ }^{1}$ \\ Received: March 21, 2020. Revised: April 27, 2020. Accepted: May 05, 2020
}

\begin{abstract}
Purpose: Prior studies empirically examine how financial flexibility is related to required returns by using realized returns and considering cash holdings as net debts, but they fail to find consistent results. Conjecturing that inappropriate proxy of required returns and aggregation of cash and debts caused the inconsistent results, this study revisits this topic by using a refined proxy of required returns and separating cash holdings from debts. Research design, data and methodology: This study uses a multivariate regression model to investigate the relationship between required returns on cash holdings and financial leverage. The required returns are estimated using the return decomposition method by vector autoregression model. Empirical tests use US stock market data from1968 to 2011 . Results: Empirical results reveal that both cash holdings and leverage are positively related to required returns. The positive relation is stronger in economic downturns than in economic upturns. Conclusions: Three major findings are drawn. First, risky firms prefer large cash balance. Second, information shocks in the realized returns caused failure of prior studies to find consistent positive relationship between leverage and realized returns. Third, cash and leverage are related to required returns in the same direction; therefore, cash cannot be considered as negative debts.
\end{abstract}

Keywords: Financial Flexibility, Cash Holdings, Leverage, Vector Autoregression, Return Decomposition.

JEL Classification Code: M41, G12, E44

\section{Introduction}

This study investigates the relation between expected returns and financial flexibility of firms. Financial flexibility is one of traditional concepts in finance, however, prior studies have not directly investigated how financial flexibility is related to expected returns. Some studies on leverage partially investigate this issue, but, they use inaccurate proxies of expected returns or leverage. This

\footnotetext{
* This study is based on one essay of my dissertation. I thank my dissertation chair Woon Oh Jung and committee members Lee -seok Hwan, Jong Hag Choi, Kyung-Ho Park, and Seung Yeon Lim for the guidance and support. I am also grateful to seminar participants at Seoul National University for their useful comments. 1 First Author and Corresponding Author. Assistant Professor, Faculty of College of Business Administration, Kookmin University, Republic of Korea. Email: yimsg@kookmin.ac.kr

(c) Copyright: The Author(s)

This is an Open Access article distributed under the terms of the Creative Commons Attribution Non-Commercial License (https://creativecommons.org/licenses/by-nc/4.0/) which permits unrestricted non-commercial use, distribution, and reproduction in any medium, provided the original work is properly cited.
}

study revisits this issue by improving prior studies research design.

The frictions of external financing could incur financial constraints, which could cause underinvestment (Le \& Kim, 2020). As a firm's dependence on external financing increases, the underinvestment problem by market friction becomes more severe (Denis, 2011). Therefore, reducing the dependence on external financing is helpful to mitigate the influence of financial constraints to maximize firm value.

In addition to the underinvestment problem, the dependence on external financing also affects a firm's systematic risks. External financing is tied to macroeconomic conditions; hence, the dependence on external financing makes a firm's investment exposed to macroeconomic conditions (Campello, Graham, \& Harvey, 2010). As a consequence, the firm's systematic risks would increase as the dependence on external financing increases. Therefore, investors would increase the required returns as a firm's dependence on external financing.

The conjecture above highlights the importance of financial flexibility, which is "the ability of a firm to 
respond in a timely and value-maximizing manner to unexpected changes in the firm's cash flows or investment opportunity set" (Denis, 2011, p. 667). As the dependence on external financing decreases, a firm's financial flexibility increases. This study examines the relationship between financial flexibility and the required returns.

Among several aspects of financial flexibility, this study focuses on two aspects, namely, cash holdings and financial leverage, because of the following reasons. First, they are directly related to the financing of investment projects. Cash holdings reduce the demand for external financing (Kim, Mauer, \& Sherman, 1998), and financial leverage is one of the major factors that limit borrowing. Second, these two aspects can be easily observed on the financial statements; thus, investors can easily utilize them in determining required returns. Third, and most importantly to this study, these two aspects are frequently regarded as two sides of the coin in prior studies. Therefore, conceptual and economic differences between cash holdings and leverage are not fully considered in prior studies (Acharya, Almeida, \& Campello, 2007).

The relationship between cash holdings and required returns are not investigated independently. Those prior studies assume that cash holdings are negative debts (Acharya et al., 2007); thus, the relationship between cash holdings and required returns is studied as a part of leverage impact (Fama \& French, 1992). Recent studies on cash holdings provide empirical results on how cash holdings and realized returns are related; however, the relationship between required returns and cash holdings has not been explored.

The relationship between default risk and leverage is well- known both theoretically and practically (Modigliani \& Merton, 1958), which suggests that leverage should be positively related to required returns because. Despite wellestablished theory, empirical studies fail to find a consistent positive relationship between financial leverage and proxy for required returns. One potential reason is the inappropriate use of the proxy for required returns. Prior studies generally use realized returns as the proxy for required returns; however, required returns include not only required returns but also information shocks that are related to unexpected economic events (Elton, 1999). Therefore, using realized returns as proxy for the required returns could cause bias test return. In addition, as aforementioned, these studies calculated financial leverage assuming that cash holdings are negative debts. This view assumes that cash holdings and debts may seem disparate but are actually related; however, as Acharya et al. (2007) point out, the role of cash holdings is not limited to repaying debts. This means that mixing debts with cash holdings could cause bias in empirical results.
Based on the conjecture above, this study examines that required returns are related to cash holdings and leverage. Based on the well-established theory, this study hypothesizes that financial leverage and required returns are positively related. Studies on cash holdings argue that a precautionary motive is the primary motive of cash holdings. According to this view, firms reserve cash to respond to the unprepared capital demand. Therefore, cash holdings could decrease firm risk by insulating the firm from the friction of external financing and preventing financial constraints, which could decrease required returns. Alternatively, because cash holdings provide financial slack, risky firms would increase cash reserves to prepare for the constraint of external financing. If this is the case, the level of cash holdings would be a measure of firm risks; therefore, cash holdings and required returns would change in the same direction. In sum, the relationship between required returns and cash holdings is an empirical question.

The remainder of this paper is structured as follows. Section 2 summarizes prior studies and develops hypotheses. Section 3 explains the empirical designs, and Section 4 presents the main empirical results. Section 5 supplements the results in Section 4 with additional tests. Section 6 concludes the overall findings.

\section{Literature Review and Hypotheses}

\subsection{Financial Flexibility}

Market frictions hinder external financing; therefore, firms that rely on external financing have a high risk of financial constraint. These firms should invest in short-term and low-risk investment projects because of the difficulty of external financing, which incurs the underinvestment problem (Almeida, Campello, \& Weisbach, 2011). To avoid the consequences of financial constraints, firms enhance the ability to invest independently from external financing, which is financial flexibility. Financial flexibility enables firms to avoid underinvestment problem.

Financial flexibility can be obtained by several methods. Among those, most preferred method is reserving cash. Cash holdings are resources with the least financing frictions; hence, cash assets are the most convenient source of financing (Bates, Kahle, \& Stulz, 2009). Borrowing is another important part of financial flexibility. In addition to their importance, cash holdings and financial leverage can be easily observed from accounting information.

Prior studies report that cash holdings are closely related to firm risks. As market competition becomes more severe, firms reserve large cash assets to prepare potential capital needs for investments to beat competitors (Haushalter, Klasa, \& Maxwell, 2007). Moreover, cash holdings insulate 
firms from the shock of external financing (Campello et al., 2010).

These studies provide two opposite predictions on the relation between cash holdings and required returns. If precautionary motive of cash holdings reduces firm risk, required returns could decrease as a firm reserve more cash assets. Alternatively, since risky firms need more cash, required returns and cash holdings could be related positively.

Prior studies on leverage suggest that high leverage suppresses investment on positive net present value projects (Myers, 1977). Consequently, large debts endanger the long-term survival of firms in a severe product market competition (Ferrarini, Hinojales, \& Scaramozzino, 2017; Ferrarini \& Hinojales, 2019). In sum, a high level of financial leverage is expected to increase the firm's default risk and decrease product market performance.

\subsection{Empirical Studies on the Relation between Financial Flexibility and Required Returns}

Empirical results on the relation between cash holdings and realized returns are found in several studies (Simutin, 2010; Kim \& Lee, 2020). However these studies are not complete to address the relation between cash holdings and required returns because realized returns are not an ideal proxy for required returns.

Elton (1999) points out that realized returns are composed of required returns and information shocks. The information shocks which caused by unexpected economic events. As addressed above, cash holdings are closely related to firms' economic outcomes. This means that cash holdings are associated with information shocks. Therefore, using realized returns as the proxy for required returns can be biased.

If cash holdings decrease firm risks from financial constraints, cash holdings and required returns will be correlated negatively. If this is the case, the positive relation reported in prior studies are the results of information shocks. Alternatively, because risky firms should reserve cash balance for precautionary purposes, both cash holdings and required return increase as firm risks increase. This derives the positive relationship between cash holdings and required return. To the best of my knowledge, no study has directly related cash holdings and information shocks to explain the results in prior studies.

Despite well-established finance theory, empirical evidences on the relation between leverage and required returns are inconsistent (Bhandari, 1988; Fama \& French, 1992; Johnson, 2004; Penman, Richardson, \& Tuna, 2007; George \& Hwang, 2010). These studies use realized returns as the proxy for the required returns. Leverage causes underinvestment, therefore, leverage could cause negative information shocks. If this is the case, the influence of information shocks would cancel out the positive relation between leverage and required returns.

\subsection{Cash Holdings and Debts}

Empirical studies on financial leverage frequently use net debts in calculating financial leverage, that is, debts less cash holdings, assuming that cash is equivalent to negative debts. This point of view connects cash holdings only to borrowing, but not to share issuance, dividend payouts, or operating activities. Although some studies find that firms have cash holdings to alleviate default risk from debts (Acharya, Davydenko, \& Strebulaev, 2012), debts can explain the motives of cash holdings only partly.

Acharya et al. (2007) argue that cash holdings can be useful to hedge profitable investment projects, meaning that increase of cash balance is not for reduction of debts but for future investment. McLean (2011) supports the argument that cash holdings mitigate the time gap between capital needs and cash inflows by showing that firms issue shares, not debts, to reserve cash assets. Moreover, McLean (2011) shows that cash holdings need not be tied to debts because share issuance can be utilized to reserve internal cash. Therefore, the net debt concept, not separating cash and debts, can mislead empirical results in several contexts including the effect of cost of capital of cash holdings and financial leverage.

\subsection{Hypothesis Development}

A firm solely relying on external financing could suffer from underinvestment because market friction could impede external financing for investments. Cash holdings alleviate financial constraints by providing alternative financing sources, which is the main motivation of cash holdings. Therefore, as the likelihood of financial constraint increases, a firm would increase cash holdings (Acharya et al., 2012). In this scenario, cash holdings are an indicator of firm risks; thus, cash holdings and required returns would exhibit a positive correlation.

Alternatively, cash holdings could be negatively related to required returns. Cash holdings reduce dependence on external financing and thus decrease a firm's association with the external market. Therefore, systematic risks from capital market decrease as cash holdings decrease, which leads to the reduction of required returns (Baimukhamedova, Baimukhamedova \& Luchaninova, 2017).

Both contradicting scenarios are reasonable. Therefore, 
the first hypothesis is presented in a null form.

H1: Cash holdings and required returns are not related.

Financial leverage increases default risks; thus, asset pricing theory predicts positive relationship between financial leverage and required returns. Alternatively, to avoid potential default, firms in imperfect capital markets would strategically manage their level of leverage (George $\&$ Hwang, 2010). The result of the financial leverage management would lead to a negative relationship between financial leverage and default risk. If this is the case, required returns would be negatively related to financial leverage. Based on the two scenarios, the second hypothesis is also prepared in a null form as well.

H2: Financial leverage and required returns are not related.

\section{Research Design}

\subsection{Regression Model}

This study uses the following multivariate regression model to test the hypotheses:

$$
\begin{gathered}
\operatorname{ret}_{t+1}=\alpha+\beta_{1} F F_{t}+\beta_{2} \text { Beta }_{t}+\beta_{3} \ln M E_{t}+\beta_{4} \ln \left(\frac{B}{M}\right)_{t} \\
+\varepsilon_{t+1} \cdots \cdots \cdots \cdots
\end{gathered}
$$

Variable definitions are presented in the Appendix. The dependent variable is the proxy for required excess returns. Both realized excess and expected excess returns are used to confirm that information shocks cause bias in the results. Expected excess returns are measured using the vector autoregression (VAR) method explained in the next section. $F F$ is cash holdings or financial leverage. The level of cash holdings or the level of financial leverage could vary by industry or year. This study uses the year-industry decile to alleviate the measurement error problem. Market beta, market capitalization, and book-to-market ratio of equity are included to control the effect of known risk factors.

To examine the relationship between information shocks and financial flexibility, model (1) is applied by changing the dependent variable into information shocks that are also estimated using the VAR method.

\subsection{Return Decomposition by VAR method}

The return decomposition method of Vuolteenaho (2002) is used to divide realized returns into expected returns, cash flow shocks, and discount factor shocks. The following is the VAR model (Yim, 2020):

$$
\left(\begin{array}{c}
r_{t+1} \\
r_{t+1} e_{t+1} \\
b m_{t+1}
\end{array}\right)=\left(\begin{array}{lll}
\alpha_{1} & \alpha_{2} & \alpha_{3} \\
\beta_{2} & \beta_{2} & \beta_{3} \\
\gamma_{1} & \gamma_{2} & \gamma_{3}
\end{array}\right)\left(\begin{array}{c}
r_{t} \\
r o e_{t} \\
b m_{t}
\end{array}\right)+\left(\begin{array}{l}
\eta_{1 t+1} \\
\eta_{2 t+1} \\
\eta_{3 t+1}
\end{array}\right)
$$

Variable definitions are presented in the appendix. The estimated expected return is

$$
\hat{r}_{t+1}=\hat{\alpha}_{1} r_{t}+\hat{\alpha}_{2} \text { roe }_{t}+\hat{\alpha}_{3} b m_{t} .
$$

Information shocks can be measured in two ways depending on where residuals are assigned. Following Vuolteenaho (2002), first, discount rate shocks is estimated. Then, residuals are assigned to cash flow shocks as follows:

$$
\begin{aligned}
& -\mathrm{N} r_{t}=-N_{1}^{\prime} \boldsymbol{\eta}_{t} \\
& \mathrm{~N} e_{t}=\left(\boldsymbol{e}_{1}+\lambda_{1}\right)^{\prime} \boldsymbol{\eta}_{t} \\
& \text { where } \boldsymbol{e}_{\boldsymbol{k}}^{\prime}=(0, \ldots 1, \ldots 0) \text { and } \lambda_{k}^{\prime}=\boldsymbol{e}_{\boldsymbol{k}}^{\prime} \rho \boldsymbol{\Gamma}(\mathbf{I}-\rho \boldsymbol{\Gamma})^{-1}
\end{aligned}
$$

Alternatively, cash flow shocks can be calculated first. In this method, discount rate shocks include all the residuals.

$$
\begin{aligned}
& \mathrm{N} e_{t}=\left(\boldsymbol{e}_{2}^{\prime}+\lambda_{2}^{\prime}\right)^{\prime} \boldsymbol{\eta}_{t} \\
& -\mathrm{N} r_{t}=-\left(\boldsymbol{e}_{\mathbf{2}}^{\prime}-\boldsymbol{e}_{\mathbf{1}}^{\prime}+\lambda_{\mathbf{2}}^{\prime}\right) \boldsymbol{\eta}_{t}
\end{aligned}
$$

The difference between the two methods is where residuals are assigned. Although Vuolteenaho (2002) argues that cash flow shocks are noisier than discount rate shocks, the nature of residuals in equations (5) and (6) is unclear. Therefore, information shocks measured by both methods will be examined in the empirical test of this study.

\section{Empirical Analyses}

\subsection{Sample and Descriptive Statistics}

The US stock market data from 1968 to 2011 was collected from Compustat and the Center for Research in Security Prices (CRSP). Financial firms and firms in the regulated industry are excluded from the sample. The final sample has 99,323 observations.

Table 1 shows the descriptive statistics of the variables. The mean and median of RealRet show that RealRet is right-skewed, which could be due to information shocks. Relatively higher volatility of RealRet supports this conjecture. Among the information shocks, residually measured shocks $\left(-N r_{-} R\right.$ and $\left.N e \_R\right)$ are more volatile than estimated shocks $\left(-N r_{-} E\right.$ and $\left.N e_{-} E\right)$. 
Table 1: Descriptive Statistics

\begin{tabular}{|c|c|c|c|c|c|}
\hline & Avg. & \multicolumn{1}{c|}{ STD } & \multicolumn{1}{c|}{$\mathbf{2 5 \%}$} & $\mathbf{5 0 \%}$ & $\mathbf{7 5 \%}$ \\
\hline RealRet & 8.77 & 52.55 & -24.48 & 0.93 & 31.23 \\
\hline ExpRet & 0.45 & 7.70 & -4.13 & 0.42 & 5.14 \\
\hline$-N r \_E$ & 1.69 & 19.65 & -8.65 & -0.41 & 8.65 \\
\hline Ne_R & 8.55 & 42.76 & -17.79 & 3.41 & 27.58 \\
\hline$-N r \_R$ & 11.37 & 110.70 & -18.82 & -1.63 & 19.19 \\
\hline Ne_E & 7.87 & 52.90 & -10.27 & 5.62 & 21.89 \\
\hline RCASH & 5.52 & 2.82 & 3.00 & 6.00 & 8.00 \\
\hline RLEV & 5.51 & 2.83 & 3.00 & 6.00 & 8.00 \\
\hline FinFlex & 0.50 & 0.23 & 0.33 & 0.50 & 0.67 \\
\hline Beta & 1.19 & 0.75 & 0.72 & 1.11 & 1.56 \\
\hline In(ME) & 11.73 & 2.18 & 10.11 & 11.57 & 13.23 \\
\hline
\end{tabular}

Note: All the returns are measured annually and presented in perce ntage unit.

\subsection{Returns and Measures of Financial Flexibility}

Figure 1 displays the means of RealRet and ExpRet by the decile of cash holdings. Both RealRet and ExpRet increase as RCASH increases. This graph implies that risky firms prefer liquidity assets (Son, 2015). External financing is costly to risky firms; thus risky firms have incentive to hoard cash assets to avoid underinvestment problem. Figure 1 support this conjecture. Both RealRet and ExpRet show increasing trend, implying that information shocks do not cancel out the relation between expected returns and cash holdings.

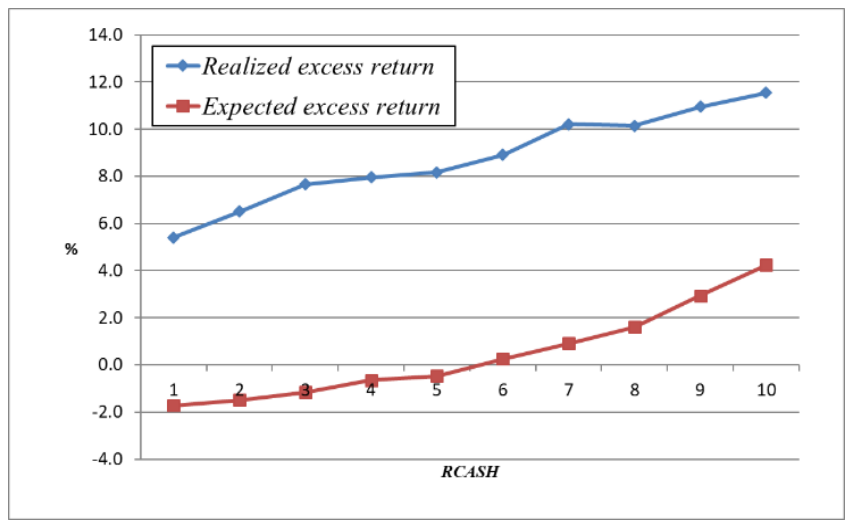

Figure 1: Returns by Cash Holdings Decile

Figures 2 reports the means of proxies for expected returns by leverage decile. Expected returns show strict increasing trend except for the first leverage decile, which is consistent with the prediction of finance theory. Realized returns show a weak relation with leverage decile. Figure 2 suggest that information shocks are the reason that previous studies have failed to find positive relation between expected returns and financial leverage.

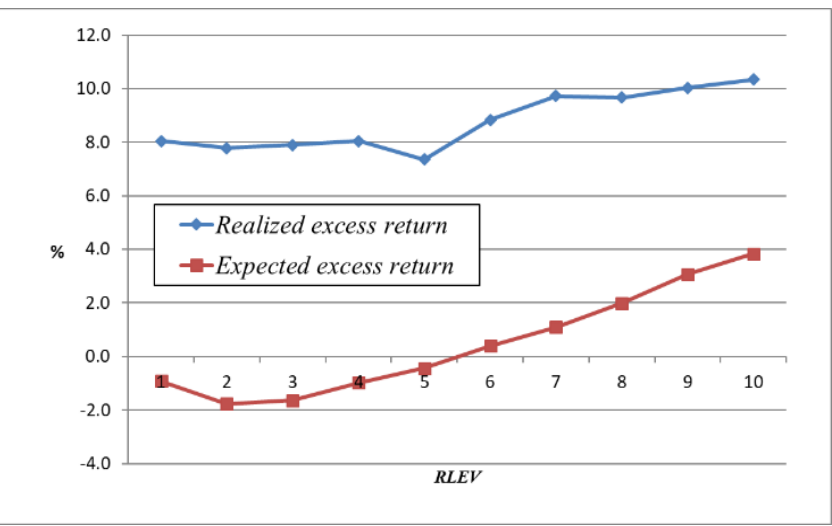

Figure 2: Returns by Leverage Decile

\subsection{Regression Analysis}

Table 2 presents the results of the pooled regression analysis. The coefficient of $R C A S H$ is positive in columns (1) and (2), suggesting that risky firms prefer cash holdings for precautionary purpose.d However, although the sign is the same, the coefficient in column (1) is larger than that in column (2), suggesting that cash holdings are related to positive information shocks. This implies that risky firms with large cash holdings show stock performance better than the market required, which is probably due to higher profitability or lower systematic risk than investors' prediction. In sum, the results in columns (1) and (2) imply that the investors required returns based on the risk that is related to a firm's cash holding policy; however, investors do not consider the positive impact of cash holdings for reducing the cost of financial constraint.

Columns (3) and (4) show the relationship between financial leverage and returns. The coefficient of $R L E V$ is significantly positive only in column (4), which is consistent with the prediction of finance theory. As presented in column (3), realized returns have insignificant relation with leverage, suggesting that allowing information shocks as the proxy for required returns could bias test results for required returns.

Both cash and leverage are positively related to ExpRet. Cash holdings and leverage can be aggregated into one if they are oppositely related to required returns. However, the coefficients have a similar sign, which means that cash holdings and debts are not the opposite concept. As Acharya et al. (2007) argue, the hedging role of cash holdings explains the positive coefficient of cash holdings. Therefore, the test results reject the assumption that cash holdings are negative debts. 
Table 2: Cash Holdings and Leverage on Returns

\begin{tabular}{|c|c|c|c|c|}
\hline Variables & $\begin{array}{c}(1) \\
\text { RealRet }\end{array}$ & $\begin{array}{c}(2) \\
\text { ExpRet }\end{array}$ & $\begin{array}{c}\text { (3) } \\
\text { RealRet }\end{array}$ & $\begin{array}{c}(4) \\
\text { ExpRet }\end{array}$ \\
\hline RCASH & $\begin{array}{c}0.371^{* * *} \\
(6.36)\end{array}$ & $\begin{array}{c}0.108^{* * *} \\
(8.70)\end{array}$ & & \\
\hline$R L E V$ & & & $\begin{array}{l}-0.076 \\
(-1.30)\end{array}$ & $\begin{array}{c}0.083^{* * *} \\
(6.08)\end{array}$ \\
\hline Beta & $\begin{array}{c}-0.739^{* * *} \\
(-3.32)\end{array}$ & $\begin{array}{c}-0.424^{\star * *} \\
(-9.57)\end{array}$ & $\begin{array}{c}-0.586^{* * *} \\
(-2.65)\end{array}$ & $\begin{array}{c}-0.375^{\star \star *} \\
(-8.51)\end{array}$ \\
\hline $\operatorname{InME}$ & $\begin{array}{c}0.177^{\star *} \\
(2.23)\end{array}$ & $\begin{array}{c}-0.307^{\star * *} \\
(-10.02)\end{array}$ & $\begin{array}{l}0.110 \\
(1.40)\end{array}$ & $\begin{array}{c}-0.329^{* \star *} \\
(-10.97)\end{array}$ \\
\hline $\ln (B / M)$ & $\begin{array}{c}2.807^{\star * *} \\
(13.30)\end{array}$ & $\begin{array}{c}4.287^{* \star *} \\
(34.53)\end{array}$ & $\begin{array}{c}3.294^{* * *} \\
(15.32)\end{array}$ & $\begin{array}{c}4.295^{\star * *} \\
(33.65)\end{array}$ \\
\hline YearDummy & Yes & Yes & Yes & Yes \\
\hline $\begin{array}{l}\text { Observations } \\
\text { Adj R-sq. }\end{array}$ & $\begin{array}{c}99,323 \\
0.180\end{array}$ & $\begin{array}{c}99,323 \\
0.452\end{array}$ & $\begin{array}{c}99,323 \\
0.180\end{array}$ & $\begin{array}{c}99,323 \\
0.452\end{array}$ \\
\hline
\end{tabular}

Note: The pooled regression results, coefficients, and statistical significance are presented in this table. ${ }^{*},{ }^{* *}$, and ${ }^{* * *}$ denote $\mathrm{t}$ wo-tailed significance at $10 \%, 5 \%$, and $1 \%$, respectively. Firm-c luster adjusted t-statistics are in the parentheses.

Both $R C A S H$ and $R L E V$ are included in the model to confirm that the results in Table 2 are not subsumed by each other. The results are documented in Table 3 . The pooled regression results presented in columns (1) and (2) are qualitatively consistent with the results in Table 2. To further confirm that intertemporal correlation does not bias the result, the regression was estimated using FamaMcBeth regression; the results are shown in columns (3) and (4). The significant result is found only in the regression using expected returns as the dependent variable, which supports the conjecture that information shocks in the realized returns could cause bias. Moreover, the results in column (4) are qualitatively similar to the pooled regression results, implying the robustness of the results.

Previous analyses are based on the assumption that information shocks and financial flexibility have significant relations that could incur bias in the empirical tests. To confirm this conjecture, RCASH and RLEV are regressed on information shocks. Test results are presented in Table 4.

The coefficients of RCASH and RLEV are positively significant except for that of RCASH in column (1), meaning that cash holdings and financial leverage are related to information shocks. Information shocks in realized returns are the stock movements related to economic events that are previously unknown or unexpected. The assumption of using realized returns as the proxy for expected returns states that the information shocks do not have systematic relation with the variable of interest, in this paper, cash holdings or leverage (Elton, 1999). However, the results in Table 4 show that the assumption is violated, which means that using realized returns as a proxy for required returns is inappropriate.

Table 3: Combined Effect of Cash and Leverage on Returns

\begin{tabular}{|c|c|c|c|c|}
\hline \multirow{2}{*}{ Variables } & \multicolumn{2}{|c|}{ Pooled regression } & \multicolumn{2}{|c|}{ Fama-McBeth Reg. } \\
\hline & $\begin{array}{c}\text { (1) } \\
\text { RealRet }\end{array}$ & $\begin{array}{c}(2) \\
\text { ExpRet }\end{array}$ & $\begin{array}{c}\text { (3) } \\
\text { RealRet }\end{array}$ & $\begin{array}{c}(4) \\
\text { ExpRet }\end{array}$ \\
\hline RCASH & $\begin{array}{c}0.367^{\star \star * *} \\
(6.26)\end{array}$ & $\begin{array}{c}0.122^{* \star *} \\
(9.75)\end{array}$ & $\begin{array}{l}-0.016 \\
(-0.35)\end{array}$ & $\begin{array}{c}0.185^{\star *} \\
(2.41)\end{array}$ \\
\hline$R L E V$ & $\begin{array}{l}-0.024 \\
(-0.40)\end{array}$ & $\begin{array}{c}0.101^{* * *} \\
(7.29)\end{array}$ & $\begin{array}{l}-0.080 \\
(-1.59)\end{array}$ & $\begin{array}{l}0.209^{*} \\
(1.82)\end{array}$ \\
\hline Beta & $\begin{array}{c}-0.739^{* * *} \\
(-3.31)\end{array}$ & $\begin{array}{c}-0.426^{* * *} \\
(-9.62)\end{array}$ & $\begin{array}{l}0.532 \\
(1.27)\end{array}$ & $\begin{array}{l}-0.947 \\
(-0.97)\end{array}$ \\
\hline $\operatorname{InME}$ & $\begin{array}{c}0.177^{\star *} \\
(2.23)\end{array}$ & $\begin{array}{c}-0.307^{* \star *} \\
(-10.06)\end{array}$ & $\begin{array}{l}-0.081 \\
(-0.67)\end{array}$ & $\begin{array}{c}1.229^{\star * *} \\
(5.37)\end{array}$ \\
\hline $\ln (B / M)$ & $\begin{array}{c}2.841^{* * *} \\
(12.49)\end{array}$ & $\begin{array}{c}4.144^{\star \star *} \\
(32.59)\end{array}$ & $\begin{array}{c}-0.857^{* * *} \\
(-4.14)\end{array}$ & $\begin{array}{c}-4.550^{* * *} \\
(-7.80)\end{array}$ \\
\hline Constant & & & $\begin{array}{l}1.606 \\
(0.99)\end{array}$ & $\begin{array}{c}-9.897^{* * *} \\
(-3.32)\end{array}$ \\
\hline YearDummy & Yes & Yes & No & No \\
\hline $\begin{array}{l}\text { Observations } \\
\text { Adj R-sq. }\end{array}$ & $\begin{array}{c}99,323 \\
0.180\end{array}$ & $\begin{array}{c}99,323 \\
0.453\end{array}$ & $\begin{array}{c}99,323 \\
0.034\end{array}$ & $\begin{array}{c}99,323 \\
0.037\end{array}$ \\
\hline
\end{tabular}

Note: Columns (1) and (2) document the pooled regression res ults. Coefficients and statistical significance are also presented. ${ }^{*},{ }^{* *}$, and ${ }^{* * *}$ denote two-tailed significance at $10 \%, 5 \%$, and $1 \%$, respectively. Firm-cluster adjusted t-statistics are in the par entheses. The results in column (3) and (4) are estimated usin g Fama-McBeth regression that

estimates the first-stage regression cross-sectionally.

Table 4: Cash Holdings and Leverage on Returns

\begin{tabular}{|c|c|c|c|c|}
\hline Variables & $\begin{array}{c}(1) \\
-N r \_E\end{array}$ & $\begin{array}{c}(2) \\
N e \_R\end{array}$ & $\begin{array}{c}(3) \\
-N r \_R\end{array}$ & $\begin{array}{c}(4) \\
N e \_E\end{array}$ \\
\hline$R C A S H$ & $\begin{array}{l}-0.028 \\
(-1.10)\end{array}$ & $\begin{array}{c}0.326^{\star * \star} \\
(6.62)\end{array}$ & $\begin{array}{c}1.474^{\star * *} \\
(9.33)\end{array}$ & $\begin{array}{l}0.133^{*} \\
(1.94)\end{array}$ \\
\hline$R L E V$ & $\begin{array}{c}-0.111^{* \star *} \\
(-4.15)\end{array}$ & $\begin{array}{c}0.147^{\star * *} \\
(2.93)\end{array}$ & $\begin{array}{c}0.491^{* * *} \\
(3.41)\end{array}$ & $\begin{array}{c}0.305^{\star * *} \\
(4.39)\end{array}$ \\
\hline Beta & $\begin{array}{c}0.845^{\star * *} \\
(8.54)\end{array}$ & $\begin{array}{c}-0.855^{\star * *} \\
(-4.45)\end{array}$ & $\begin{array}{c}5.950^{\star * *} \\
(9.89)\end{array}$ & $\begin{array}{c}-1.240^{* *} \\
(-2.10)\end{array}$ \\
\hline InME & $\begin{array}{c}-0.120^{\star * *} \\
(-2.91)\end{array}$ & $\begin{array}{c}0.245^{\star * *} \\
(3.51)\end{array}$ & $\begin{array}{c}-4.301^{* * *} \\
(-19.69)\end{array}$ & $\begin{array}{c}1.302^{\star * *} \\
(11.27)\end{array}$ \\
\hline $\ln (B / M)$ & $\begin{array}{c}-0.467^{* * *} \\
(-4.62)\end{array}$ & $\begin{array}{c}-1.903^{\star * *} \\
(-9.35)\end{array}$ & $\begin{array}{c}-7.646^{* * *} \\
(-11.15)\end{array}$ & $\begin{array}{c}-3.945^{\star * *} \\
(-11.45)\end{array}$ \\
\hline YearDummy & Yes & Yes & Yes & Yes \\
\hline $\begin{array}{l}\text { Observations } \\
\text { Adj R-sq. }\end{array}$ & $\begin{array}{c}99,323 \\
0.093\end{array}$ & $\begin{array}{c}99,323 \\
0.131\end{array}$ & $\begin{array}{c}99,323 \\
0.025\end{array}$ & $\begin{array}{c}99,323 \\
0.038\end{array}$ \\
\hline
\end{tabular}

Note: The pooled regression results, coefficients, and statistical significance are presented in this table. ${ }^{*},{ }^{* *}$, and ${ }^{* * *}$ denote twotailed significance at $10 \%, 5 \%$, and $1 \%$, respectively. Firm-cluster adjusted t-statistics are in the parentheses. 


\section{Additional Tests}

Additional tests examine the influence of macroeconomic condition on the main tests of this study. Risk premium should be higher in economic downturns; hence, additional tests can confirm whether the results of the main tests are related to firm risks.

Financial flexibility is more useful in an economic downturn than in economic expansion periods because access to external financing is harder. Financially flexible firms are affected less by external economic conditions, which decrease systematic risks. Therefore, risk premiums should be larger in economic downturns than in economic upturns. Based on the conjecture above, this section confirms that the relationships between expected returns and the measures of financial flexibility are due to systematic risks.

For the additional test, the sample period is divided by expected market conditions. Prior studies point out that realized market returns could be a biased measure of market condition for asset pricing test because realized returns include new information that cannot be expected ex ante (Petkova \& Zhang, 2005). Following this argument, the expected market return is used to divide the sample period. Following Petkova and Zhang (2005), the expected market risk premium is estimated by month. This is the model to estimate market risk premium:

$$
\begin{aligned}
& R_{m \omega}=\alpha+\beta_{1} D I V_{\omega-1}+\beta_{2} D E F_{\omega-1}+\beta_{3} T E R M_{\omega-1} \\
& \quad+\beta_{4} R f_{\omega-1}+\varepsilon
\end{aligned}
$$

The expected market premium is defined as

$$
\begin{aligned}
& \hat{R}_{m \omega}=\alpha+\hat{\beta}_{1} D I V_{\omega-1}+\hat{\beta}_{2} D E F_{\omega-1}+\hat{\beta}_{3} T E R M_{\omega-1} \\
& \quad+\hat{\beta}_{4} R f_{\omega-1}
\end{aligned}
$$

By compounding expected market premiums of 12 months from July of year $t$, annualized expected market premium of year $t$ is calculated. If the annualized market premium of the year is less (greater) than the first quartile of the annualized market premiums among the sample periods, the year is classified as an economic downturn (upturn).

The analysis in Table 2 is modified by including the interaction term between RCASH (RLEV) and Upturn (Dnturn). Table 5 documents the results. In column (1), the coefficient of $R L E V$ is negative, which is opposite to the theory's prediction. Moreover, Dnturn also has a negative coefficient. This result is also contradicting the theory because risk premium should increase in the economic downturn. In sum, the table shows that the dependent variable of column (1) is an inappropriate proxy of required returns.

In column (2), coefficients of RCASH and RLEV are positive, which is consistent with the previous result. More importantly, the two interaction terms of Dnturn also have positive coefficients, meaning that the premium on risks related to cash holdings or leverage increase in the economic downturn. These results support the interpretation that the positive relationship between RCASH (RLEV) and expected returns estimated by the VAR method varies according to firm risks.

The results about the economic downturn are consistent with the results about the economic upturn. In column (4) of Table 4, RCASH and RLEV have positive coefficients. Moreover, the coefficients on the two interaction terms are all negative, indicating that that risk premium on the risks related to cash holdings or financial leverage decrease in the economic upturn. This result is consistent with the theory. By contrast, the result in column (3) is not strictly consistent with the theory, suggesting that realized returns,

\begin{tabular}{|c|c|c|c|c|}
\hline Variables & $\begin{array}{c}(1) \\
\text { RealRet }\end{array}$ & $\begin{array}{c}(2) \\
\text { ExpRet }\end{array}$ & $\begin{array}{c}\text { (3) } \\
\text { RealRet }\end{array}$ & $\begin{array}{c}\text { (4) } \\
\text { ExpRet }\end{array}$ \\
\hline $\mathrm{RCASH}$ & $\begin{array}{c}0.357^{\star * \star} \\
(5.21)\end{array}$ & $\begin{array}{c}0.099^{* * *} \\
(7.42)\end{array}$ & $\begin{array}{c}0.367^{\star * *} \\
(5.66)\end{array}$ & $\begin{array}{c}0.148^{* * *} \\
(11.20)\end{array}$ \\
\hline$R L E V$ & $\begin{array}{c}-0.249^{* * *} \\
(-3.62)\end{array}$ & $\begin{array}{c}0.074^{* * *} \\
(5.09)\end{array}$ & $\begin{array}{l}0.053 \\
(0.82)\end{array}$ & $\begin{array}{c}0.110^{* * *} \\
(7.49)\end{array}$ \\
\hline Upturn & & & $\begin{array}{c}-10.429^{*} \\
* * \\
(-6.34)\end{array}$ & $\begin{array}{l}0.291 \\
(1.12)\end{array}$ \\
\hline Dnturn & $\begin{array}{c}-5.148^{\star \star \star} \\
(-3.27)\end{array}$ & $\begin{array}{l}0.059 \\
(0.24)\end{array}$ & & \\
\hline Upturn $^{\star} R C A S H$ & & & $\begin{array}{l}-0.020 \\
(-0.16)\end{array}$ & $\begin{array}{c}-0.104^{* *} \\
(-5.24)\end{array}$ \\
\hline Upturn $^{*} R L E V$ & & & $\begin{array}{c}-0.299^{* *} \\
(-2.29)\end{array}$ & $\begin{array}{c}-0.045^{\star *} \\
(-2.20)\end{array}$ \\
\hline Dnturn $^{*} R C A S H$ & $\begin{array}{l}-0.012 \\
(-0.11)\end{array}$ & $\begin{array}{c}0.091^{* * *} \\
(5.03)\end{array}$ & & \\
\hline Dnturn ${ }^{\star} R L E V$ & $\begin{array}{c}0.973^{\star \star *} \\
(8.12)\end{array}$ & $\begin{array}{c}0.108^{\star * *} \\
(5.67)\end{array}$ & & \\
\hline Beta & $\begin{array}{c}-0.802^{* * *} \\
(-3.60)\end{array}$ & $\begin{array}{c}-0.427^{* *} \\
(-9.63)\end{array}$ & $\begin{array}{c}-0.751^{* *} \\
(-3.37)\end{array}$ & $\begin{array}{c}-0.424^{* *} \\
(-9.57)\end{array}$ \\
\hline $\operatorname{InME}$ & $\begin{array}{c}0.170^{* *} \\
(2.14)\end{array}$ & $\begin{array}{c}-0.308^{* *} \\
* \\
(-10.10)\end{array}$ & $\begin{array}{c}0.177^{\star *} \\
(2.23)\end{array}$ & $\begin{array}{c}-0.309^{* *} \\
* \\
(-10.13)\end{array}$ \\
\hline $\ln (B / M)$ & $\begin{array}{c}2.860^{\star \star \star *} \\
(12.61)\end{array}$ & $\begin{array}{c}4.151^{* * *} \\
(32.76)\end{array}$ & $\begin{array}{c}2.856^{\star \star \star *} \\
(12.57)\end{array}$ & $\begin{array}{c}4.153^{\star * *} \\
(32.78)\end{array}$ \\
\hline Year Dummy & Yes & Yes & Yes & Yes \\
\hline $\begin{array}{l}\text { Observations } \\
\text { Adj R-sq. }\end{array}$ & $\begin{array}{c}99,323 \\
0.180\end{array}$ & $\begin{array}{c}99,323 \\
0.454\end{array}$ & $\begin{array}{c}99,323 \\
0.180\end{array}$ & $\begin{array}{c}99,323 \\
0.454\end{array}$ \\
\hline
\end{tabular}
the dependent variable of column (3), is an inappropriate proxy of required returns.

Table 5: Effect of Economic Condition

Note: The pooled regression results, coefficients, and statistical significance are presented in this table. ${ }^{*},{ }^{* *}$, and ${ }^{* * *}$ denote twotailed significance at $10 \%, 5 \%$, and $1 \%$, respectively. Firm-cluster adjusted t-statistics are in the parentheses. 


\section{Conclusion}

This study examines the relationship between returns and proxies for financial flexibility using the VAR return decomposition method. The empirical findings can be summarized as follows. First, risky firms prefer asset liquidity, which induces a positive association between cash holdings and required returns. Second, if information shocks are removed, required returns and financial leverage shows strictly positive relation, meaning that information shocks in realized returns causes inconsistent empirical results in the studies on the relationship between financial leverage and required returns. Third, in determining required returns, investors do not consider cash holdings as negative debts. Therefore, net debt concepts could be one of the reasons for previous studies' failure to find a positive relationship between leverage and required returns. Finally, the results are stronger in recession periods, which confirms that the results are driven by firm risks.

The analysis results of this study provide the following implications. Our empirical results show that in valuations of companies, investors focus more on the risks that make firms to reserve large cash balance than on the hedging role of cash. While it is clear that a cash asset is a useful investment source, having an investment source is not enough to eliminate the risks arising from operating activities, and the company's operating risk is reduced only if appropriate investments and subsequent results are followed. The relationship between cash equivalents and required returns presented in this study is consistent with this explanation.

In addition, the results of this study on leverage and required returns remind the significance of the stock price response to new information, namely information shocks, in empirical tests. Many empirical studies implicitly assume that required returns are the only systematic part of the stock returns. However, as well known in both theory and practice, stock prices are updated to reflect new information. The reason that prior studies failed to find inconsistent results on the relation between leverage and required returns might be inappropriate proxy for required returns. This is the second implication of this study.

This study contributes to the literature in several points. First, consistent with the expectation of theory, this study finds that financial leverage is positively related to expected returns. Second, this study suggests that using realized returns as the proxy for expected returns could bias test results. Although Elton (1999) points out that information surprises, realized returns are widely used as the proxy for expected returns. The use of realized returns might be an explanation for inconclusive empirical test results for default risk (Dichev, 1998), because distressed firms could experience negative information shocks due to discontinued investments or failure to meet financial obligations. Finally, this study supports that cash holdings are not negative debt. The results of this study show that both cash holdings and debts are positively associated with expected returns, implying that cash holdings should not be treated as an opposite concept of debts.

This study also has the following limitations. First, the return decomposition method fully depends on a limited number of variables in determining expected returns. Those determinants may not be the only ones that affect expected returns. If this is the case, expected returns in this study might miss some portion of returns that can be estimated $e x$ ante. Second, because the calculation of the proxy for expected returns relies on the VAR model, the validity of my proxy depends on the validity of the VAR model. For example, if the influence of a determinant lasts longer than one period, estimation would be biased. Future studies could suggest a better method to address the limitations in this study.

Despite these limitations, finding an information-shockfree proxy for required returns is worth examining because the shocks could bias the test results. Furthermore, as firms prefer financial flexibility to external financing, stock price reaction to financial flexibility should be examined precisely. At this point, this study has practical and academic implications.

\section{References}

Acharya, V. V., Almeida, H., \& Campello, M. (2007). Is cash negative debt? A hedging perspective on corporate financial policies. Journal of Financial Intermediation, 16(4), 515-554.

Acharya, V. V., Davydenko, S. A., \& Strebulaev, I. A. (2012). Cash holdings and credit risk. Review of Financial Studies, 25(12), 3572-3609.

Almeida, H., Campello, M., \& Weisbach, M. S. (2011). Corporate financial and investment policies when future financing is not frictionless. Journal of Corporate Finance, 17(3), 675-693.

Baimukhamedova, A., Baimukhamedova, G., \& Luchaninova, 1. (2017). Financial Disclosure and the Cost of Equity Capital: The Empirical Test of the Largest Listed Companies of Kazakhstan. The Journal of Asian Finance, Economics and Business, 4(3), 5-17.

Bates, T. W., Kahle, K. M., \& Stulz, R. M. (2009). Why do US firms hold so much more cash than they used to? Journal of Finance, 64(5), 1985-2021.

Bhandari, L. C. (1988). Debt/equity ratio and expected common stock returns: Empirical evidence. The Journal of Finance, 43(2), 507-528.

Campello, M., Graham, J. R., \& Harvey, C. R. (2010). the real effects of financial constraints: Evidence from a financial crisis. Journal of Financial Economics, 97(3), 470-487.

Denis, D. J. (2011). Financial flexibility and corporate liquidity. Journal of Corporate Finance, 17(3), 667-674.

Dichev, I. D. (1998). Is the risk of bankruptcy a systematic risk? 
The Journal of Finance, 53(3), 1131-1147.

Elton, E. J. (1999). Expected return, realized return, and asset pricing tests. The Journal of Finance, 54(4), 1199-1220.

Fama, E. F., \& French, K. R. (1992). The cross-section of expected stock returns. The Journal of Finance, 47(2), 427465.

Ferrarini, B., \& Hinojales, M. (2019). State-Owned Enterprises and Debt Sustainability Analysis: The Case of the People's Republic of China. The Journal of Asian Finance, Economics and Business, 6(1), 91-105.

Ferrarini, B., Hinojales, M., \& Scaramozzino, P. (2017). Chinese Corporate Leverage Determinants. The Journal of Asian Finance, Economics and Business, 4(1), 5-18.

George, T. J., \& Hwang, C.-Y. (2010). A resolution of the distress risk and leverage puzzles in the cross section of stock returns. Journal of Financial Economics, 96(1), 56-79.

Haushalter, D., Klasa, S., \& Maxwell, W. F. (2007). The influence of product market dynamics on a firm's cash holdings and hedging behavior. Journal of Financial Economics, 84(3), 797-825.

Johnson, T. C. (2004). Forecast dispersion and the cross section of expected returns. The Journal of Finance, 59(5), 1957-1978.

Kim, S.-S., \& Lee, J. H. (2016). The Marginal Value of Cash and Agency Conflicts in Korean Firms. The Journal of Asian Finance, Economics and Business, 3(4), 5-16.

Kim, C.-S., Mauer, D. C., \& Sherman, A. E. (1998). The Determinants of Corporate Liquidity: Theory and Evidence.
Journal of Financial \& Quantitative Analysis, 33(3), 335-359.

Le, A. H., \& Kim, T. (2020). The Effects of Economic Freedom on Firm Investment in Vietnam. The Journal of Asian Finance, Economics and Business, 7(3), 9-15.

McLean, D. R. (2011). Share issuance and cash savings. Journal of Financial Economics, 99(3), 693-715.

Modigliani, F., \& Merton, H. M. (1958). The Cost of Capital, Corporation Finance and the Theory of Investment. The American Economic Review, 48(3), 261-297.

Myers, S. C. (1977). Determinants of corporate borrowing. Journal of Financial Economics, 5(2), 147-175.

Penman, S. H., Richardson, S. A., \& Tuna, İ. (2007). The book-toprice effect in stock returns: Accounting for leverage. Journal of Accounting Research, 45(2), 427-467.

Petkova, R., \& Zhang, L. (2005). Is value riskier than growth? Journal of Financial Economics, 78(1), 187-202.

Simutin, M. (2010). Excess cash and stock returns. Financial Management, 39(3), 1197-1222.

Son, S.-H. (2015). A Study on the Cash Policies of Retail Firms. Journal of Distribution Science, 13(3), 69-77.

Vuolteenaho, T. (2002). What drives firm-level stock returns? The Journal of Finance, 57(1), 233-264.

Yim, S.-G. (2020). The Pricing of Accruals Quality with Expected Returns: Vector Autoregression Return Decomposition Approach. The Journal of Industrial Distribution \& Business, 11(3), 7-17. 


\section{Appendix. Variable Definitions}

\begin{tabular}{|c|c|}
\hline \multicolumn{2}{|r|}{ Variables for the VAR model } \\
\hline$r$ & $\log (1+$ annual realized stock returns $)-\log (1+30$-day Treasury bill rate $)$, demeaned by Fama-French 48 industry \\
\hline roe & $\log (1+$ return on equity $)-\log (1+30$-day Treasury bill rate $)$, demeaned by Fama-French 48 industry groups \\
\hline$b m$ & Log(book value to market value of equity), demeaned by Fama-French 48 industry groups \\
\hline \multicolumn{2}{|r|}{ Proxies for financial flexibility } \\
\hline $\mathrm{RCASH}$ & $\begin{array}{c}\text { The industry-year decile rank of cash holdings, cash and short-term investments, divided by the market value of eq } \\
\text { uity }\end{array}$ \\
\hline$R L E V$ & $\begin{array}{r}\text { The industry-year decile rank of total debts, that is, the sum of long-term and short-term debts, divided by the mark } \\
\text { et value of equity }\end{array}$ \\
\hline \multicolumn{2}{|r|}{ Firm characteristics } \\
\hline ME & market value of equity (in million dollars) \\
\hline$B / M$ & Book value of equity to market value of equity \\
\hline InME & The natural logarithm of $M E$ \\
\hline$B / M$ & Book value to market value of equity \\
\hline $\ln (B / M)$ & The natural logarithm of $B / M$ \\
\hline Beta & Estimated beta of the market model calculated with monthly returns of the previous 5 years. \\
\hline \multicolumn{2}{|r|}{ Returns } \\
\hline RealRet & Annual realized excess stock return less annualized Treasury bond rate \\
\hline ExpRet & Annual expected excess return as estimated by the VAR model \\
\hline$-N r \_E$ & Discount rate shocks estimated by the VAR model. \\
\hline Ne_R & Residually calculated cash flow shocks \\
\hline$-N r \_R$ & Residually estimated discounted factor shock. \\
\hline $\mathrm{Ne} \_\mathrm{E}$ & Cash flow shocks estimated by the VAR model. \\
\hline \multicolumn{2}{|r|}{ Variables for the expected market premium } \\
\hline$R_{m}$ & Returns on market portfolio \\
\hline DIV & $\begin{array}{l}\text { The dividend yield, calculated as total cash dividends payment of entire Compustat database for the recent year div } \\
\text { ided by the total market value of all firms in the Compustat database of the previous year }\end{array}$ \\
\hline$D E F$ & $\begin{array}{c}\text { The default spread, defined as the difference between the yield of 10-year Treasury bonds and the yield of 1-year } \\
\text { Treasury bonds }\end{array}$ \\
\hline TERM & $\begin{array}{c}\text { The term spread, defined as the difference between the yield of AAA rate long-term corporate bond and the yield } 0 \\
\text { f BAA rate long-term corporate bond. }\end{array}$ \\
\hline$R f$ & Annualized one-month Treasury bond rate \\
\hline \multicolumn{2}{|r|}{ Market condition variable } \\
\hline $\begin{array}{l}\text { Dnturn } \\
\text { (Uptern) }\end{array}$ & $\begin{array}{c}1 \text { if the annualized expected market premium is in the fourth (first) quartile, } 0 \text { otherwise. The annualized expected } \\
\text { market premium is calculated by compounding monthly expected market premium for the previous } 12 \text { months. Mont } \\
\text { hly market premium is estimated using equation (9) }\end{array}$ \\
\hline
\end{tabular}

